\title{
Using Wastes from the Process of Blasting with Steel Shot to Make a Radiation Shield in Mortar
}

\author{
Richard Thomas Lermen*D, Márcio Baldissera Prauchner $\mathbb{D}^{\mathbb{D}}$, Rodrigo de Almeida Silva $\mathbb{D}$ and \\ Francieli Tiecher Bonsembiante $\mathbb{D}$
}

Postgraduation Program of Civil Engineering, School of Engineering and Applied Sciences, IMED, Passo Fundo 99070-220, Brazil; marcio.prauchner@imed.edu.br (M.B.P.); rodrigo.silva@imed.edu.br (R.d.A.S.); francieli.bonsembiante@imed.edu.br (F.T.B.)

* Correspondence: richard.lermen@imed.edu.br; Tel.: +55-54-3045-6100

Received: 28 July 2020; Accepted: 16 August 2020; Published: 18 August 2020

\begin{abstract}
The waste generated from the process of steel shot blasting must be safely disposed of due to its classification, non-hazardous and non-inert, and, consequently, is sent to landfills. One of the possibilities for reusing this waste is in the cement materials industry. In this context, the aim of this study was to evaluate the addition of waste from steel shot blasting, thereby replacing natural sand, for the manufacture of cementitious material with properties that shield against ionizing radiation. Three forms of steel shot (commercial steel shot-AG1, intermediate steel shot waste-AG2, and steel shot dust-AG3) were used to replace natural sand in different proportions $(0 \%, 10 \%, 20 \%, 30 \%$, and $40 \%$ by volume). Compressive strength results were found with values above the minimum compressive strength $(20 \mathrm{MPa})$ requirement of structural concrete. The results indicated that AG1, AG2, and AG3 can be used to attenuate X-ray radiation. Regarding the reference samples (mortar developed without natural sand replacement), an increase in X-ray shielding of $76.7 \%, 72.5 \%$, and $59.3 \%$ was found for samples with AG1, AG2, and AG3, respectively. Therefore, the waste generated in the steel shot blasting process had the potential to be used in mortar developed to attenuate X-ray radiation.
\end{abstract}

Keywords: mortar; waste; steel shot blasting; X-ray shielding

\section{Introduction}

In the last years, due to industrial developments, technological advances, population growth, and, consequently, increased consumption, the uncontrolled exploitation of non-renewable resources, the increased energy consumption and the generation of a large volume of urban and industrial waste have been observed [1,2].

Among the industries that generate waste is the metallurgical industry, which, in one of its activities, uses an abrasive called steel shot for the process of preparing the surfaces of metal structures, a process known as steel shot blasting. In this process, the steel shot is worn down due to the impact against the surface of the material to be processed, thus changing the shape and size of the original steel shot. The material generated is called steel shot dust, which is a waste that NBR 10004 [3] classifies as class IIA-non-hazardous and non-inert (when not contaminated with paints, solvents, and other hazardous material). This waste needs to be properly disposed of, as set out in resolution number 313 of the National Environment Council [4] and in the National Solid Waste Policy as per Law 12,305 of 2010 [5]. The disposal used by the companies is based on sending the material to landfills and, when necessary, previous toxicity analyses are carried out and the toxic components are stabilized [6].

According to the metallurgy industry that provided the steel shot dust for the development of this work, 20 tons of this waste are generated per month. This industry is concerned with the significant 
costs and environmental impacts related to the disposal of this waste and seeks alternatives for its reuse. One of the alternatives is to use grit power as aggregate, replacing natural sand, in the development of heavy concretes and mortar, which is generally used to attenuate radiation [7-9].

Studies involving the development of materials for civil construction that have the function of attenuating radiation are very important due to the wide use of radiation techniques in various fields, such as health units carrying out radiation therapy, nuclear research facilities, as well as nuclear engineering and space technology [2,10-12]. For a long time, lead was used for X-ray protection. The utilization of lead in X-ray protection would surely be a good choice in terms of protection against radiation but for the fact that it is heavy and expensive. On the other hand, lead has many important disadvantages which limit its areas of application and usage, such as extremely high toxicity for both people and the environment, its heaviness, and low mechanic and chemical stability and inflexibility [13].

Seeking to find materials with radiation-shielding characteristics, much research has been carried out [14-19]. In the development of concrete and mortar, generally conventional aggregates (natural sand and gravel) are partially or totally replaced by heavy aggregates, such as barite $[9,20]$, steel shoot [11], and magnetite, among others [21]. For example, Waly and Bourham [22] sought to develop material for a radiation shield that used various combinations of aggregates (magnetite, lead oxide, and iron phosphorus) to replace sand. All combinations had a higher density than the reference concrete, the highest value obtained being that for concrete which contained $39 \%$ magnetite and $16 \%$ lead oxide. The combination that generated the concrete of the highest density also obtained the highest attenuation coefficient. The attenuation obtained for this combination was approximately nine times greater than that of the reference concrete. Creutz and Downes [23] prepared radiation-shielding concrete with magnetite and found that concrete with magnetite has appreciably better shielding properties than ordinary concrete. Maslehuddin et al. [11] studied the unit weight, compressive strength, radiation shielding of concrete with steel shots, and electric arc furnace slag aggregates. The results indicated that maximum gamma-ray attenuation was measured in the concrete with $100 \%$ steel shots, but the minimum gamma-ray attenuation was found in the concrete with $35 \%$ steel shots and $65 \%$ electric arc furnace slag aggregates. It should also be noted that concrete with $50 \%$ electric arc furnace slag aggregates and 50\% steel shots meets the weight and radiation requirements of radiation-shielding concrete.

Regarding the use of steel shot dust, some studies have already been carried out. Meneghel [24] evaluated the possibility of compacting the shot waste using a sintering process (metallurgy of the powder), thereby generating briquettes that could be used by industries at a future stage. The study carried out by Qomariah et al. [25] analyzed the suitability of contaminated sandblasting grit for production of cement mortars and found that substituting natural sand with waste sand develops the strength of mortar and small pores and increases the weight of mortar, but the waste was made up of sand and not steel shot. Jhamad et al. [26] replaced cement by steel shot dust and evaluated the compressive strength. It is concluded that the steel shot dust can be used as a replacement material for cement and $5 \%$ replacement of steel shot dust gives a promising result in the strength aspect and quality aspect, and it is better than the control concrete.

Although a number of experimental and theoretical works have been performed on the radiation shielding of concrete and mortar with heavy aggregate, there is still a lack of consensus on the utilization of steel shot blasting waste (steel shot dust) to improve the shielding radiation. Nevertheless, the purpose of this paper was to study the effects of using steel shot and waste derived from the process of steel shot blasting on the properties of mortar, such as compressive strength, air void, densities (wet and dry), water absorption, and effects of X-ray attenuation. 


\section{Materials and Methods}

\subsection{Materials}

CPV-ARI Portland cement (InterCement Brasil, Candiota, Rio Grande do Sul, Brazil) was used as a binder. It has the peculiarity of reaching high resistance already in the first days of application. The development of high initial strength is achieved by using a different dosage of limestone and clay in the production of clinker, as well as by finer grinding of the cement, so that, when reacting with water, it acquires high strengths with greater speed. Clinker is the same one used for the manufacture of conventional cement but remains in the mill for a longer time. The characteristics of this cement, according to the report on assays provided by the manufacturer, are shown in Table 1.

Table 1. Specification of the properties of the CPV-ARI Portland cement.

\begin{tabular}{|c|c|c|c|c|c|c|c|c|c|c|}
\hline \multirow{3}{*}{$\begin{array}{c}\text { Cement } \\
\text { Type }\end{array}$} & \multicolumn{10}{|c|}{ Physical Properties } \\
\hline & \multicolumn{2}{|c|}{ Setting Time } & \multirow{2}{*}{$\begin{array}{l}\text { Blaine } \\
\mathrm{cm}^{2} / \mathrm{g}\end{array}$} & \multirow[b]{2}{*}{$\# 200 \%$} & \multirow[b]{2}{*}{$\# 325 \%$} & \multirow{2}{*}{$\begin{array}{c}\mathrm{CS} \\
{ }^{1} \mathrm{~mm}\end{array}$} & \multirow{2}{*}{$D^{2} \mathrm{~g} / \mathrm{cm}^{3}$} & \multicolumn{3}{|c|}{ Compressive Strength (Average) } \\
\hline & $\begin{array}{l}\text { Initial } \\
\text { h:min }\end{array}$ & $\begin{array}{c}\text { Last } \\
\text { h:min }\end{array}$ & & & & & & 3 Days MPa & $\begin{array}{c}7 \\
\text { Days MPa }\end{array}$ & $\begin{array}{c}28 \\
\text { Days MPa }\end{array}$ \\
\hline CPV-ARI & 03:19 & 04:01 & 4.411 & 0.07 & 0.33 & 0.21 & 3.09 & $39.5 \pm 1.2$ & $45.3 \pm 1.2$ & $53.8 \pm 1.0$ \\
\hline \multirow{2}{*}{$\begin{array}{l}\text { Cement } \\
\text { type }\end{array}$} & \multicolumn{10}{|c|}{ Chemical Properties } \\
\hline & $\mathrm{Al}_{2} \mathrm{O}_{3} \%$ & $\mathrm{SiO}_{2} \%$ & $\mathrm{Fe}_{2} \mathrm{O}_{3} \%$ & $\mathrm{CaO} \%$ & $\mathrm{MgO} \%$ & $\mathrm{SO}_{3} \%$ & LOI $^{3} \%$ & Free $\mathrm{CaO} \%$ & I.R. ${ }^{4} \%$ & A.E. ${ }^{5} \%$ \\
\hline CPV-ARI & 4.46 & 19.28 & 3.0 & 61.86 & 2.59 & 2.95 & 3.62 & 0.97 & 0.81 & 0.68 \\
\hline
\end{tabular}

${ }^{1}$ CS: Cement Soundness; ${ }^{2}$ D: Density; ${ }^{3}$ LOI: Loss on ignition; ${ }^{4}$ I.R.: Insoluble Residue; ${ }^{5}$ A.E.: Alkaline Equivalent.

The fine aggregate used was natural sand. In Figure 1, the granulometric distribution curve can be seen. Its fineness modulus and bulk density of natural sand were 1.77 and $1470 \mathrm{~kg} / \mathrm{m}^{3}$, respectively. The water used was of drinking quality and was supplied by Corsan, Passo Fundo/RS.

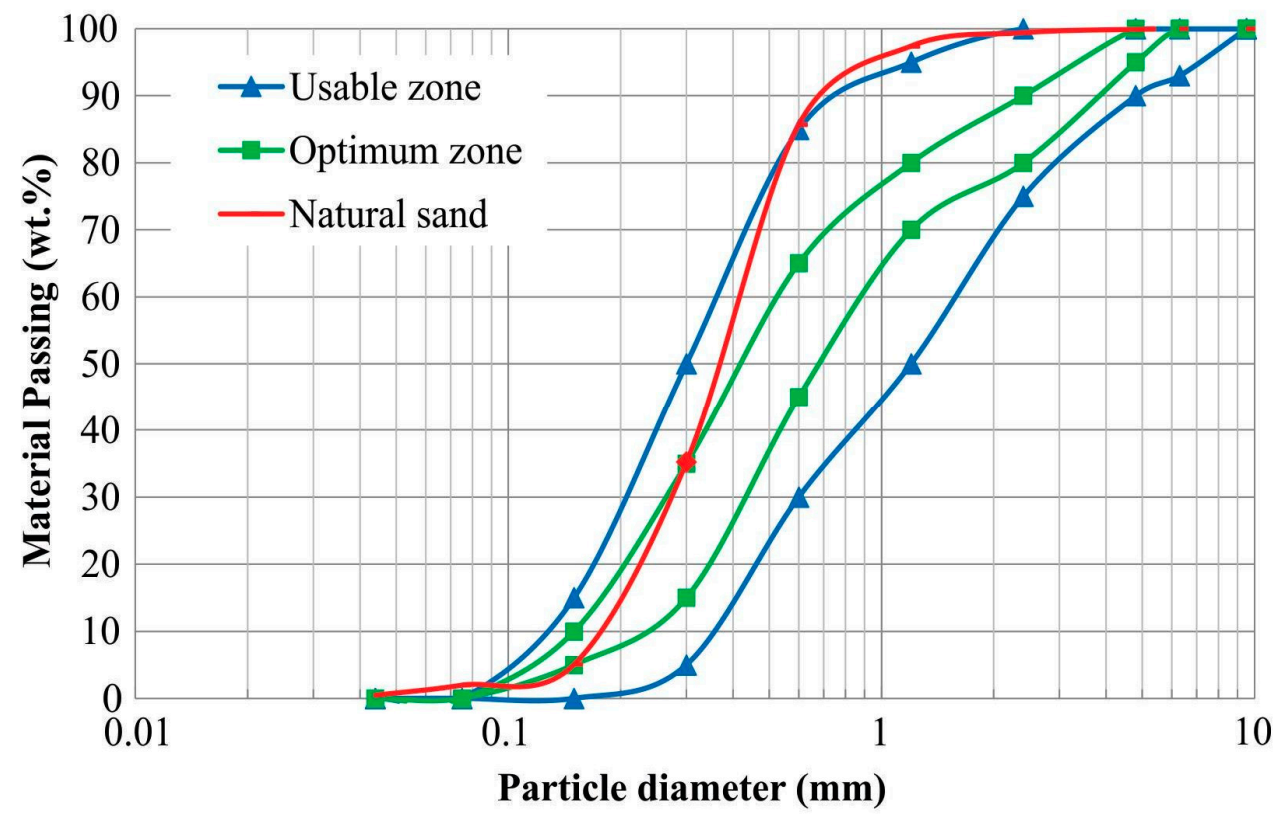

Figure 1. Granulometric curve of average and normalized sand (ABNT, 2003).

The steel shot was obtained directly from the manufacturer. It is a spherical sample type S330C. In the experimental planning, this shot was called aggregate 1 (AG1). Table 2 shows the chemical composition and properties of the steel shot supplied by the manufacturer. 
Table 2. Chemical composition and properties of the S330C steel shoot [27].

\begin{tabular}{ccccccccc}
\hline \multirow{2}{*}{ Steel Shot Type } & \multicolumn{4}{c}{ Chemical Composition (\%) } & \multicolumn{4}{c}{ Properties } \\
\cline { 2 - 9 } & C & Mn & Si & S & P & Hardness & Density & Microstructure \\
\hline S330C & 0.8 to 1.20 & 0.60 to 1.20 & $\geq 0.40$ & $\leq 0.05$ & $\leq 0.05$ & 40 to 51 & $\geq 7.0 \mathrm{~g} / \mathrm{cm}^{3}$ & Martensite \\
\hline
\end{tabular}

Steel shot waste was collected directly from the disposal containers, located around the equipment that uses steel shot in the industrial blasting process, in a metallurgical factory in the north of the Brazilian state of Rio Grande do Sul. The collection and treatment of the samples were carried out as per standard NBR 10007 [28].

The intermediate waste is characterized by a granulometry between the new steel shot and the steel shot dust and has irregular characteristics since they come from the steel shot sphere that had become worn during the industrial blasting process. This material was called aggregate 2 (AG2) in the experimental procedure. Steel shot dust is the final waste of the process and has very small particles. This waste was called aggregate 3 (AG3) in the experimental design.

Figure 2 shows the equipment used in the blasting process, where the place of entry and exit of the parts subjected to the blasting process and the location of the extractor responsible for the removal of steel shot dust (AG3) can be observed. It is important to note that not collected material (AG2) by the extractor can be reused in the system, i.e., AG2 returns to the blasting process.

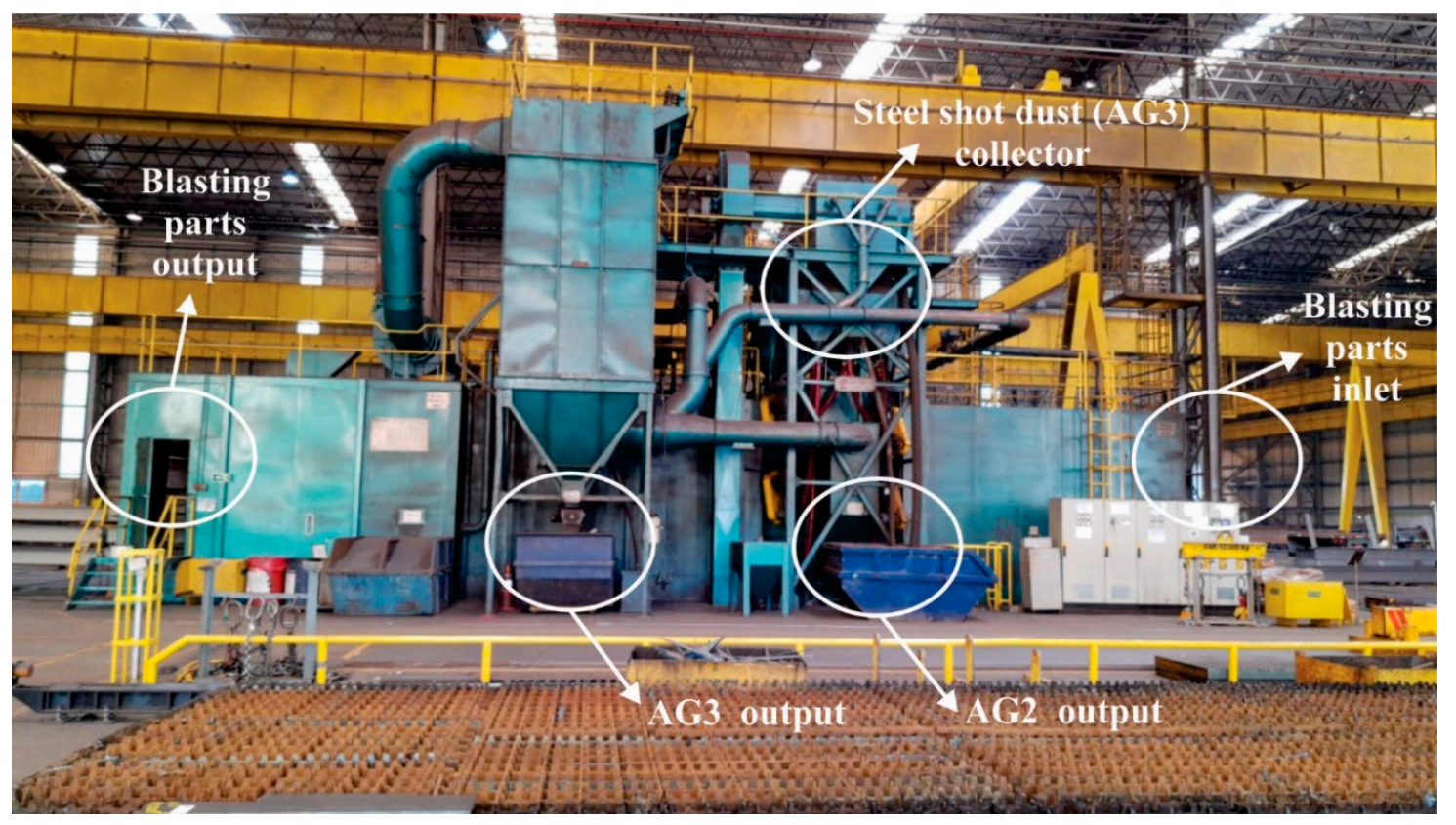

Figure 2. Blasting equipment showing the collector point for waste.

\subsection{Waste Characterization}

To characterize the materials, granulometric analysis, density, morphology, and chemical composition were determined. Granulometric analysis assays were carried out using sieving and, also, LASER granulometry. The sieving for making the granulometric analysis was performed as per the procedure set out in NBR NM 248 [29]. Cilas laser granulometer model 1190 (Anton Paar GmbH Graz, Austria), with an amplitude of measurement from 0.04 to $2500.00 \mu \mathrm{m}$, was used for particle size analysis for AG3 because it has powdery characteristics.

The pycnometry assay was performed to determine the density of the steel shot and waste, following the recommendations of the ASTM D854 standard [30]. A $500 \mathrm{~mL}$ pycnometer was used, for which the standard recommends using distilled water as a reference fluid. However, due to the hydrophobic characteristic of the wastes (AG2 and AG3), the water had to be replaced with solvent (gasoline). This 
hydrophobic characteristic is possibly related to nonpolar substances from surfaces of materials subject to the shot blasting process. To remove any bubbles, the samples remained connected to a vacuum system, generated by a compressor, for $15 \mathrm{~min}$. Analysis was performed at a temperature of $20^{\circ} \mathrm{C}$.

The iron content of the AG1, AG2, and AG3 was determined by the titanium (III) chloride reduction method, according to NBR ISO 2597-2 [31], in which the titration is based on an oxy-reduction reaction between the titrate $\left(\mathrm{Fe}^{2+}\right)$ and the titrant $\left(\mathrm{K}_{2} \mathrm{Cr}_{2} \mathrm{O}_{7}\right)$. Approximately $0.400 \mathrm{~g}$ of each sample was dissolved in $\mathrm{HCl}$ solution, reduced, oxidized, and finally titrated with a standard potassium dichromate solution to determine iron content.

To verify the morphology and elemental chemical characterization of the materials to be used as aggregates in the production of mortar, a scanning electron microscopy (SEM) assay was performed in conjunction with energy dispersive spectrometry (EDS).

The major oxides in the AG3 were determined by X-ray fluorescence spectrometry (FRX) assay, carried out on a PANalytical spectrometer, model MiniPal 4 (PANalytical B.V., Almelo, The Netherlands), at the Research Center for Petrology and Geochemistry (CPGq), Nucleus of Lithochemistry and Mineral Analysis of the Geosciences Institute at Federal University of Rio Grande do Sul (UFRGS).

\subsection{Production of Mortar Specimens and Experimental Design}

Previous experiments were carried out to determine the dosage and percentages of substitution of natural sand by steel shot blasting waste. The chosen trace was in volume due to the difference in the density of the aggregates.

The cylindrical specimens were produced as per Brazilian standard NBR 5738 [32]. Initially, the mixtures of the solids (cement + aggregates) were made, and water was added sequentially. The cement material mixing was performed by a mortar mixer with a speed of $140 \mathrm{rpm}$. After mixture homogenization, the cement mass was added to the cylindrical specimens with dimensions of $100 \times 50 \mathrm{~mm}$. The compaction was done according to the standard already mentioned. After $24 \mathrm{~h}$, the specimens were demolded and kept at room temperature $\left(25^{\circ} \mathrm{C}\right)$ for the curing process which lasted for a period of 28 days.

Table 3 shows the experimental matrix used to make the specimens. In this experimental matrix, it can be seen that the design of the experiment was built with two factors: type of aggregate (sand + aggregates) and percentage of replacement. Three levels for the aggregate type were used (AG1, AG2, and AG3) and 5 levels of substitution $(0 \%, 10 \%, 20 \%, 30 \%$, and $40 \%$ in relation to the volume of sand). For example, $1 \mathrm{dm}^{3}$ of natural sand equals $0 \%$ substitution, and $0.9 \mathrm{dm}^{3}$ of natural sand $+0.1 \mathrm{dm}^{3}$ of waste equals $10 \%$ substitution. Six specimens were molded for each combination, totaling 90 specimens.

Table 3. Experimental matrix. (W/C-water/cement ratio)

\begin{tabular}{|c|c|c|c|c|c|c|}
\hline Order & $\begin{array}{l}\text { Cement } \\
\left(\mathrm{kg} / \mathrm{m}^{3}\right)\end{array}$ & $\begin{array}{c}\text { Sand } \\
\left(\mathrm{kg} / \mathrm{m}^{3}\right)\end{array}$ & $\begin{array}{c}\text { Aggregate } \\
\left(\mathrm{kg} / \mathrm{m}^{3}\right)\end{array}$ & $\mathrm{W} / \mathrm{C}$ & $\begin{array}{l}\text { \% Replacement } \\
\text { (by Volume) }\end{array}$ & $\begin{array}{c}\text { Aggregate } \\
\text { Type }\end{array}$ \\
\hline 1 & 990 & 1470 & 0 & 0.4 & $0 \%$ & Without \\
\hline 2 & 990 & 1320 & 480 & 0.4 & $10 \%$ & AG1 \\
\hline 3 & 990 & 1180 & 980 & 0.4 & $20 \%$ & AG1 \\
\hline 4 & 990 & 1020 & 1400 & 0.4 & $30 \%$ & AG1 \\
\hline 5 & 990 & 900 & 1910 & 0.4 & $40 \%$ & AG1 \\
\hline 6 & 990 & 1320 & 460 & 0.4 & $10 \%$ & AG2 \\
\hline 7 & 990 & 1180 & 820 & 0.4 & $20 \%$ & AG2 \\
\hline 8 & 990 & 1020 & 1300 & 0.4 & $30 \%$ & AG2 \\
\hline 9 & 990 & 900 & 1680 & 0.4 & $40 \%$ & AG2 \\
\hline 10 & 990 & 1320 & 270 & 0.4 & $10 \%$ & AG3 \\
\hline 11 & 990 & 1180 & 500 & 0.4 & $20 \%$ & AG3 \\
\hline 12 & 990 & 1020 & 700 & 0.4 & $30 \%$ & AG3 \\
\hline 13 & 990 & 900 & 890 & 0.4 & $40 \%$ & AG3 \\
\hline
\end{tabular}




\subsection{Characterization of the Specimens}

The mortar specimens were subjected to the following characterization assays: compressive strength; dry and saturated bulk density; air void (apparent porosity); water absorption and X-ray transmission assay to check the attenuation generated by incorporating the waste.

\subsubsection{Compressive Strength}

Compressive strength was determined using the procedures described in the Brazilian standard NBR 5739 [33]. For this assay, an EMIC press, model PC 200C (EMIC-PC100C, Instron, Norwood, MA, USA), with a capacity of $2000 \mathrm{kN}$, breaking speed of $0.7 \mathrm{~mm} / \mathrm{min}$ and precision of approximately $1 \%$ of the applied load, was used.

\subsubsection{Dry and Wet Bulk Density, Air Void, and Water Absorption by Immersion}

Values of water absorption by immersion (\%), wet bulk density $\left(\mathrm{kg} / \mathrm{m}^{3}\right)$, dry bulk density $\left(\mathrm{kg} / \mathrm{m}^{3}\right)$, and air void (apparent porosity, \%) were obtained after testing as described by ASTM C948-81 [34] and NBR 9778 standards [35].

\subsubsection{X-Ray Attenuation}

Three cylindrical samples were used for each mix proportion to assess the properties of radiation shielding. High-frequency-generator X-ray equipment (ORANGE 1060HF model; 40-100 kV/0.32-100 $\mathrm{mA} ; 2 \times 2 \mathrm{~mm}$ focal point; Toshiba tube) was used as a radiation source. Measurements were carried out using an experimental method based on one type of detector Radcal AGMS-D+ sensor and electrometer (ACCU-GOLD+) with an interface software to show the output dose, dose-rate, time, $\mathrm{kVp}$, and Flash HVL. All samples were exposed to $70 \mathrm{kVp}$ for $1 \mathrm{~s}$. The sensor was placed $40 \mathrm{~mm}$ beneath the test samples and an X-ray source was placed $500 \mathrm{~mm}$ above the test samples. In addition to the cementitious material samples, a $1 \mathrm{~mm}$ lead rubber was used in the experiments to determine the equivalent lead thickness sequentially. Figure 3 a shows the schematic of the experimental test setup used for this study. The attenuation coefficient for each sample was determined by measuring the intensity of $X$-ray transmitted from different thicknesses by applying the Lambert Equation (1) [21,36-39]:

$$
I_{x}=I_{0} \cdot e^{-\mu(x)}
$$

where $I_{x}$ is the transmitted X-ray intensity, $I_{0}$ is the incident intensity of X-rays, $\mu$ is the linear attenuation coefficient $\left(\mathrm{mm}^{-1}\right)$, and $x$ is the thickness of the sample $(\mathrm{mm})$. The Half Value Layer (HVL) and the Tenth Value Layer (TVL) for each mortar mix were also obtained from the following Equations (2) and (3):

$$
\begin{aligned}
& H V L=\frac{\ln (2)}{\mu} \\
& T V L=\frac{\ln (10)}{\mu}
\end{aligned}
$$

Radiographic images were made to compare qualitatively the X-ray shielding, i.e., the darker the radiographic image was, the lower the radiation attenuation was. Figure $3 \mathrm{~b}$ shows the image formed of the assay with $10 \%$ of replacement to AG1.

To determine the ideal specimen size for the X-ray assays, a prior assay was carried out with the specimen in its original size, equal to those used in the other assays. However, as the result was a blockage of practically $100 \%$, the option was made to use specimens with a thickness of $19 \mathrm{~mm}$. 


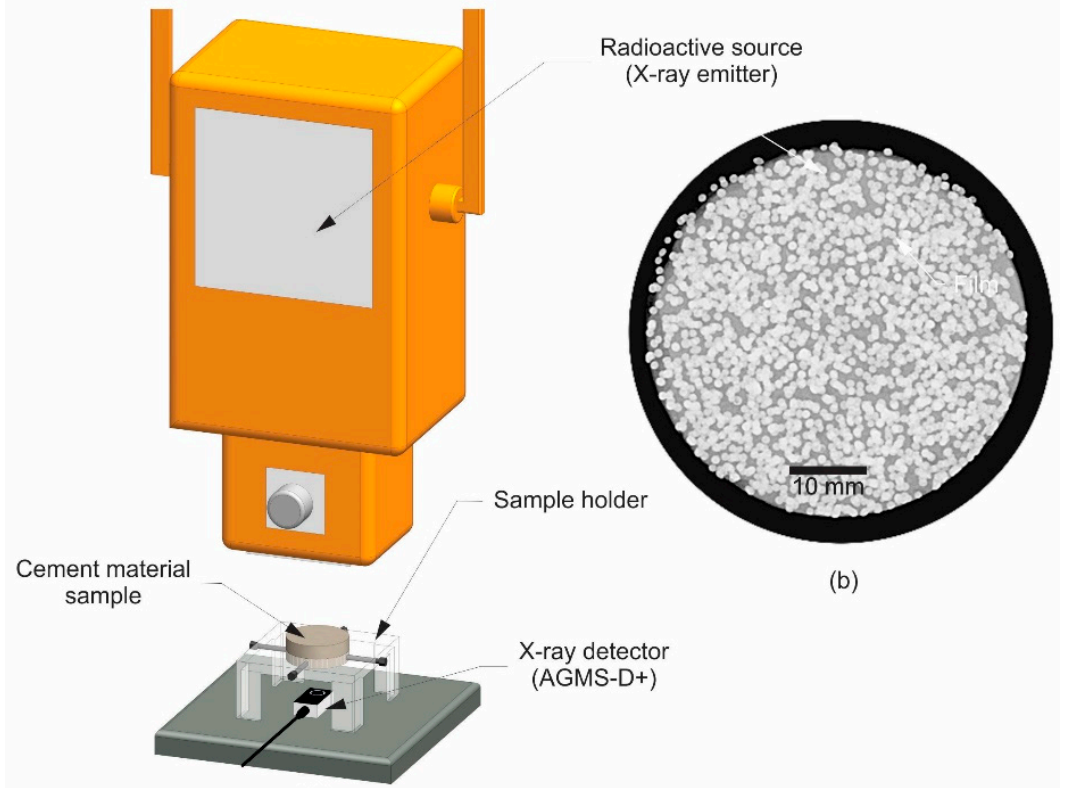

(a)

Figure 3. (a) Positioning for the X-ray attenuation assay and (b) image formed of the assay (10\% AG1).

\section{Results and Discussion}

The presentation of the results is divided into two parts, which describe the characterization of the waste used (aggregates) and the effects of the factors on the properties of the materials developed.

\subsection{Characterization of AG1, AG2, and AG3 Aggregates}

\subsubsection{Particle Size Analysis}

The results of sieving the shot and the wastes are shown in Figure 4, where the granulometric distribution curve of the AG1, AG2, and AG3 aggregates and photographs of them can be seen.

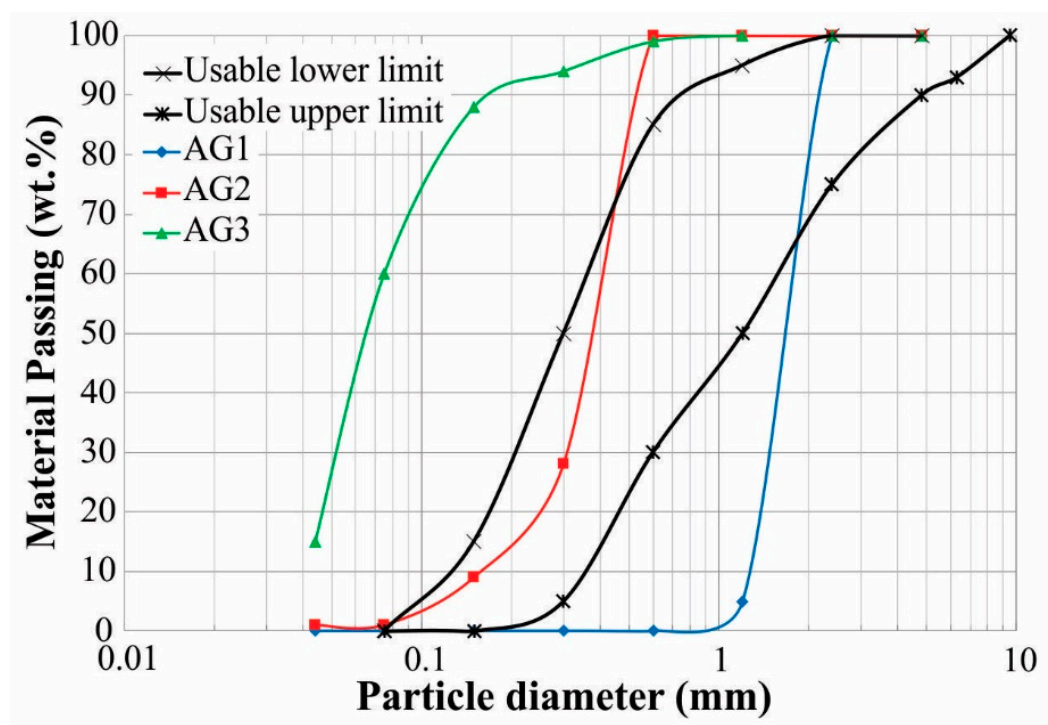

(a)
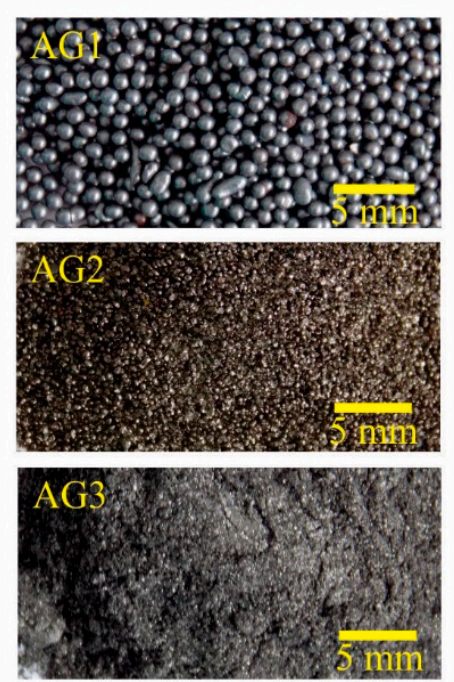

(b)

Figure 4. (a) Granulometric curve and (b) photograph of the aggregates.

For AG1, 99\% of the particles were retained in the $0.60 \mathrm{~mm}$ aperture sieve. For AG2, 72\% was retained in the $0.3 \mathrm{~mm}$ aperture sieve and $18 \%$ in the $0.15 \mathrm{~mm}$ aperture sieve. For $\mathrm{AG} 3,28 \%$ was retained 
in the $0.075 \mathrm{~mm}$ aperture sieve and $45 \%$ was retained in the $0.044 \mathrm{~mm}$ aperture sieve. The fineness modulus for AG1, AG2, and AG3, as per ASTM C136 [40], were 3.01, 1.64, and 0.17, respectively. The results of granulometry and fineness modulus for AG2 are very similar to the results found for natural sand.

Due to the large percentage of material retained in the $0.075 \mathrm{~mm}, 0.044 \mathrm{~mm}$, and bottom sieves, it was decided to analyze the AG3 by LASER granulometry. In Figure 5, the granulometric curve for AG3 can be seen, which presented an average particle diameter of $22.40 \mu \mathrm{m}$.

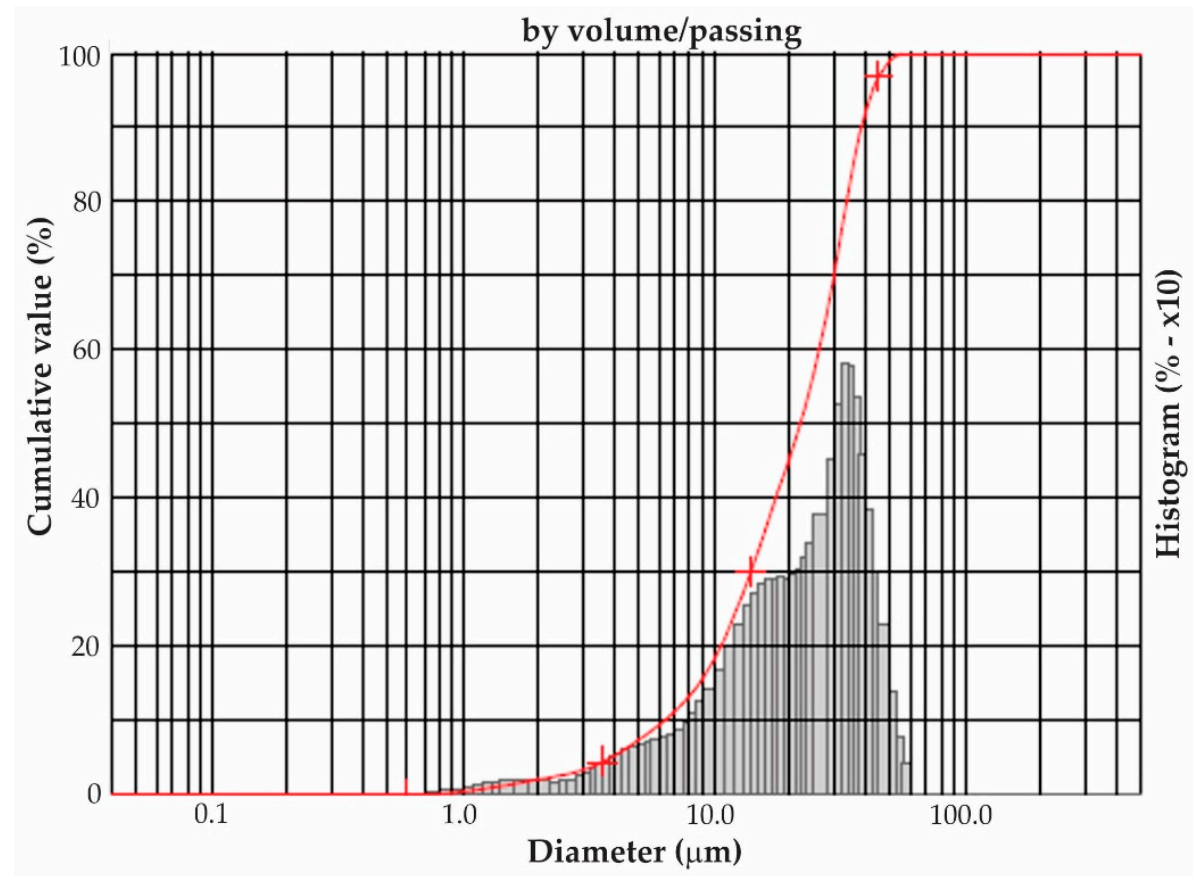

Figure 5. LASER granulometry for AG3.

\subsubsection{Density and \% Total Iron}

The results obtained from the pycnometry assays show a variation in the density of the materials according to their degree of use. AG1 obtained the highest density with $7820 \pm 80 \mathrm{~kg} / \mathrm{m}^{3}$, followed by AG2 with $7580 \pm 40 \mathrm{~kg} / \mathrm{m}^{3}$, and AG3 had the lowest density AG3, namely $7060 \pm 50 \mathrm{~kg} / \mathrm{m}^{3}$. Those results can be correlated to the utilization factor of the material in the industrial sandblasting process, i.e., the more that is used, the smaller its granulometry and, consequently, the lower its density, since, under normal conditions, without compaction, there will be a greater amount of air between the particles, thus promoting a lower density. Another aspect that can contribute to this reduction in density is the possible presence of some type of contamination, or impurities (for example, mill scale, oxidations, paintings, oils, and solvents, among others which have a large amount of components such as lead, chromium, barium, and others [24], related to the materials that were exposed to the blasting process).

In the assay performed, based on the analytical method for determining total iron [41], it was found that AG1 presented a percentage of $95.6 \pm 0.8 \%$ of total iron, AG2 presented $96.8 \pm 0.5 \%$, and AG3 presented $92.6 \pm 1.1 \%$, the latter being the lowest percentage of the three materials, which can be justified by its composition, which may contain a higher percentage of impurities.

\subsubsection{Morphology and Chemical Composition}

Figure 6 shows the morphology observed in micrographs for each of the analyzed materials. The gradual reduction in grain size starting from AG1, still unused, can be seen. The final waste (AG3) appears as small "sheets" (lamellae). The differentiated morphology of AG3 is due to the process of using shot blasting, where the shot is thrown against the metal of the structures and, due to the impact on the collision, ends up suffering wear and/or rupture. 


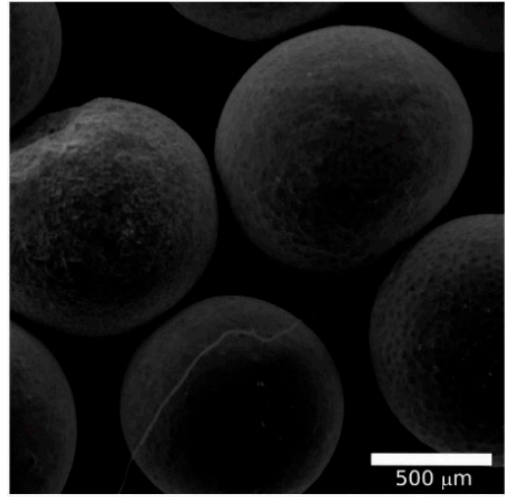

(a)

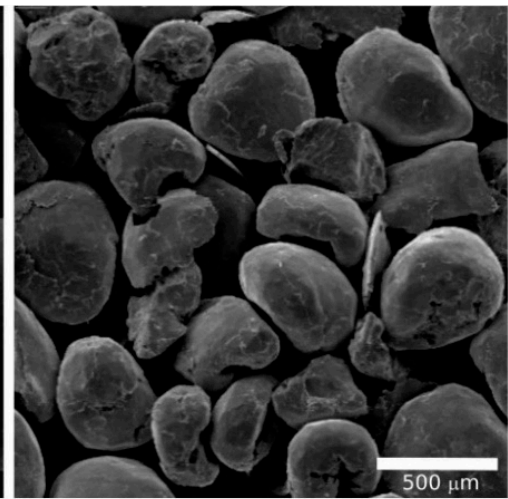

(b)

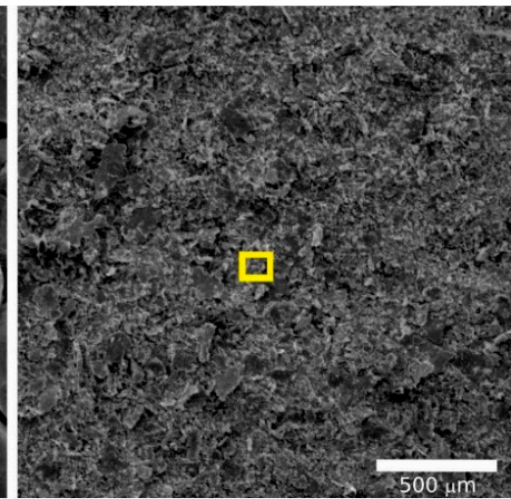

(c)

Figure 6. Morphology of the materials used as a heavy aggregate. (a) AG1, (b) AG2, and (c) AG3.

In Figure 7, the morphology can be seen of the AG2 and AG3 materials by using greater magnification. The lamellar shape in the AG3 waste and the deterioration principle due to the impact of the spheres in the AG2 waste are observed.

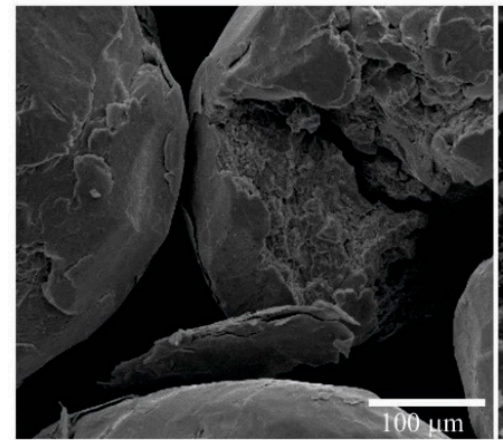

(a)

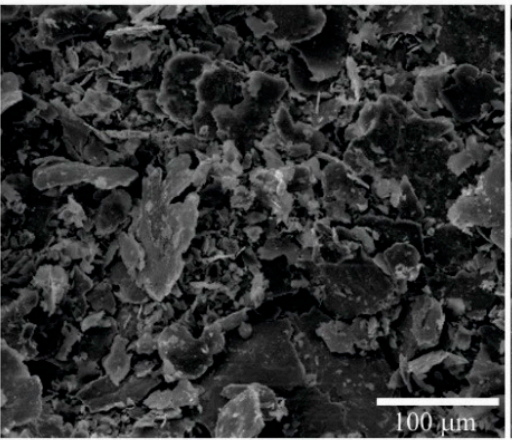

(b)

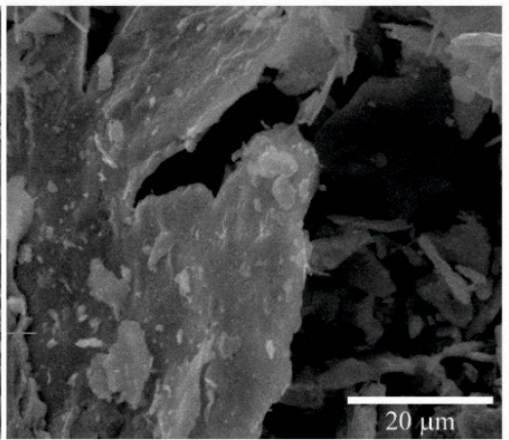

(c)

Figure 7. Morphology of the materials used as a heavy aggregate. (a) AG2, (b) AG3, and (c) AG3 with greater magnification.

Associated with scanning electron microscopy analysis, the energy dispersive spectrometer (EDS) allowed the chemical elements of the region indicated in Figure $6 \mathrm{c}$ for AG3, thus obtaining the results shown in Figure 8.

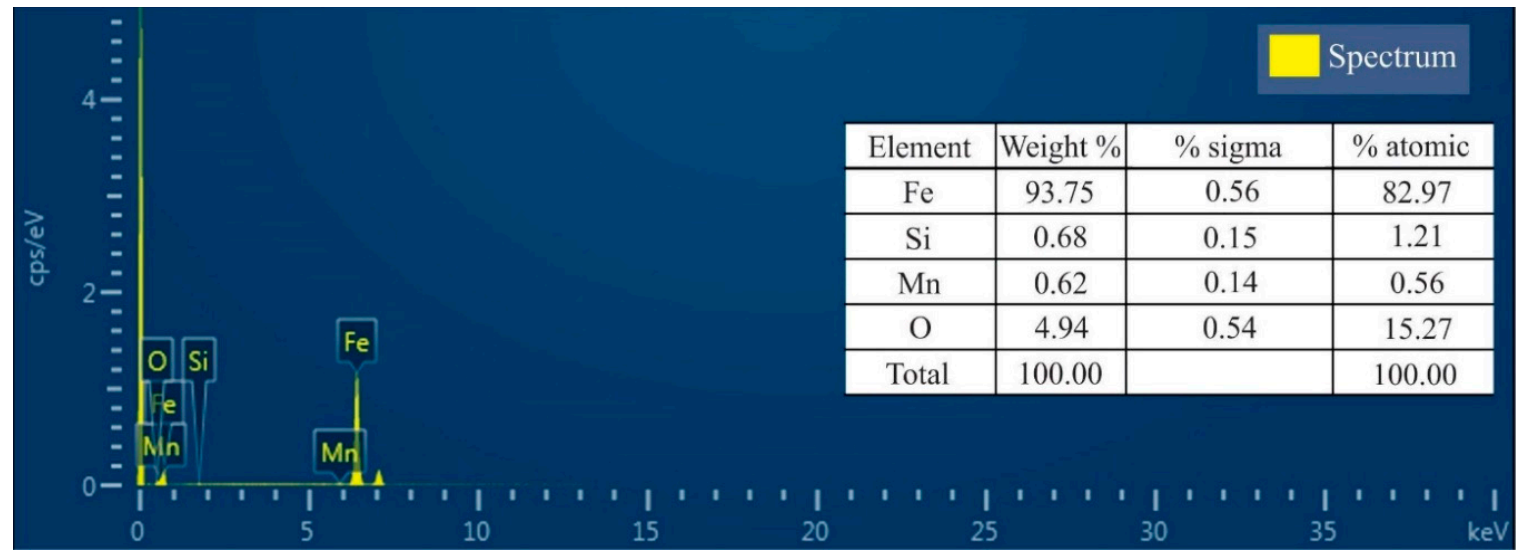

Figure 8. Energy dispersive spectrometer (EDS) showing the chemical composition for the AG3 aggregate. 
The results listed in Table 4 refer to X-ray fluorescence for the AG3 sample, obtained from quantitative analysis and performed via the fused sample technique with rock pattern calibration curves. The values are shown as a percentage of the weight of the sample.

Table 4. Chemical analysis of AG3 obtained using the X-ray fluorescence assay.

\begin{tabular}{|c|c|c|c|c|c|c|c|c|c|c|c|c|c|}
\hline \multirow{2}{*}{ Description } & \multicolumn{13}{|c|}{ Oxides (\%) } \\
\hline & $\mathrm{Fe}_{2} \mathrm{O}_{3}$ & $\mathrm{Al}_{2} \mathrm{O}_{3}$ & $\mathrm{SiO}_{2}$ & $\mathrm{MnO}$ & $\mathrm{CaO}$ & $\mathrm{Cr}_{2} \mathrm{O}_{3}$ & $\mathrm{Cl}$ & $\mathrm{CuO}$ & $\mathrm{SO}_{3}$ & $\mathrm{ZnO}$ & $\mathrm{NiO}$ & $\mathrm{MoO}_{3}$ & Total \\
\hline Amount & 95.453 & 1.352 & 1.031 & 0.782 & 0.476 & 0.317 & 0.309 & 0.090 & 0.075 & 0.073 & 0.022 & 0.02 & 100.0 \\
\hline
\end{tabular}

\subsection{Compressive Strength}

Figure 9 shows the behavior of the compressive strength of the materials produced according to the type of aggregate used and their replacement percentages. AG1 and AG2 aggregates showed increasing compressive strength values up to $20 \%$ replacement. For higher percentages, there was a decrease in the compressive strength, which fell below the compressive strength values of the reference mortar. AG3 showed decreasing results for compressive strength. Despite the lower results for the $40 \%$ replacement, the values obtained were above the minimum compressive strength $(20 \mathrm{MPa})$ requirement of a structural concrete [42].

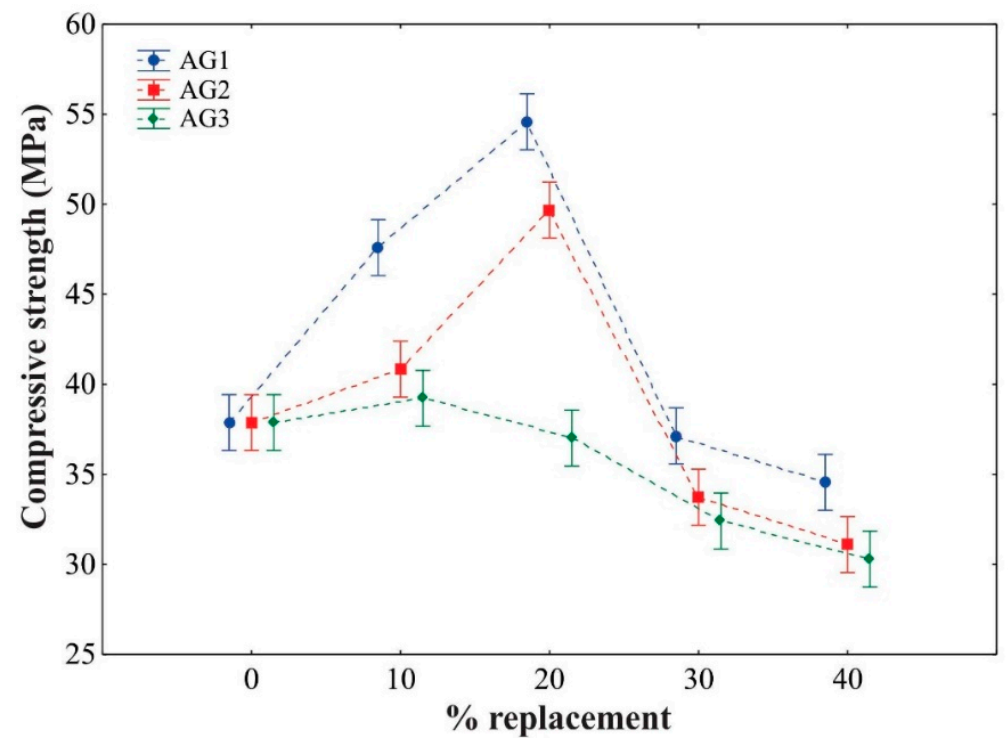

Figure 9. Compressive strength according to the percentage of replacement of aggregates and types of aggregates.

Figure 6 shows that AG1 and AG2 wastes have a more rounded morphological characteristic, which may explain the increase in compressive strength. However, AG3 has a more lamellar characteristic as can be seen in Figure $7 \mathrm{~b}, \mathrm{c}$ and also because of the size of its particles, which are smaller than those of the other aggregates. As the size of these particles is very small, consequently there is a large surface area and therefore, there is a greater need for water to hydrate the cement and can lead to the weakening of the interfacial zone between the AG3 and the cement paste. Furthermore, it is possible that the contamination of the AG3 causes a lack of adequate adhesion to the C-S-H matrix. As the water/cement ratio was fixed, this aspect may have influenced the behavior of the compressive strength of AG3.

Kan et al. [43] obtained the lowest result of compressive strength with a mixture of $10 \%$ aggregates and the highest value with a mixture of $40 \%$ metallic aggregates. This behavior was not observed in this research because for $40 \%$ of substitution, the lowest values of compressive strength of mortars were obtained. In the research by Esen and Doğan [44], the higher the percentage of replacement of the 
aggregate was, the lower the result for compressive strength was, i.e., the behavior was more similar to the results obtained in this study.

\subsection{Air Void, Water Absorption, and Dry and Wet Bulk Densities}

Figure 10 shows the graphs of the air void, water absorption, saturated bulk density, and dry bulk density as a function of the percentage of substitution for the different aggregates.

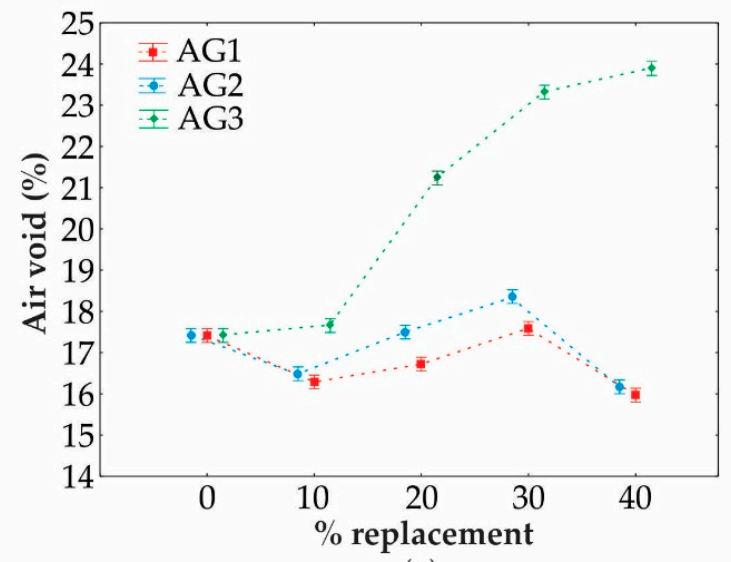

(a)

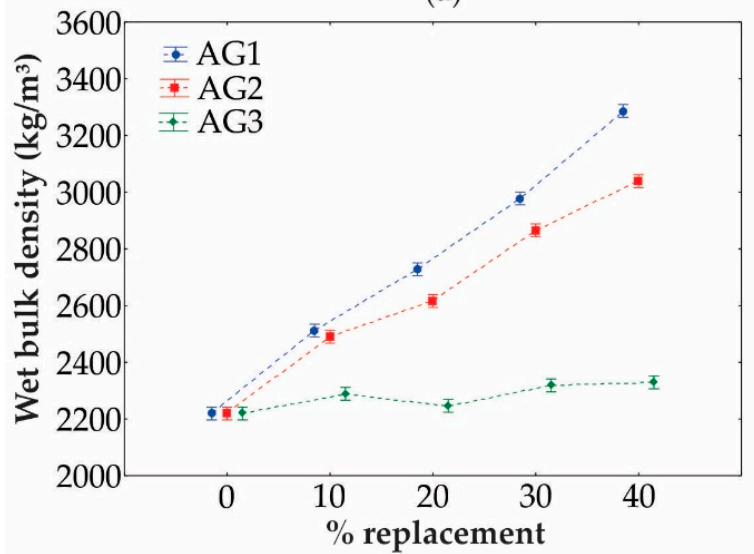

(c)

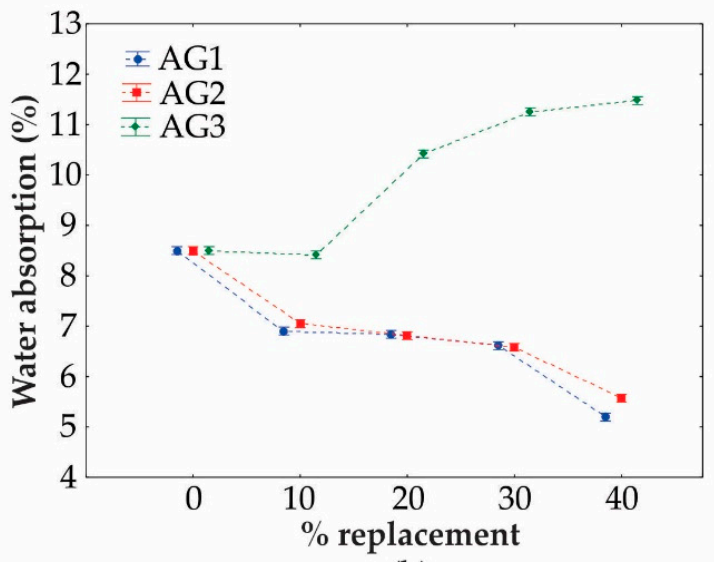

(b)

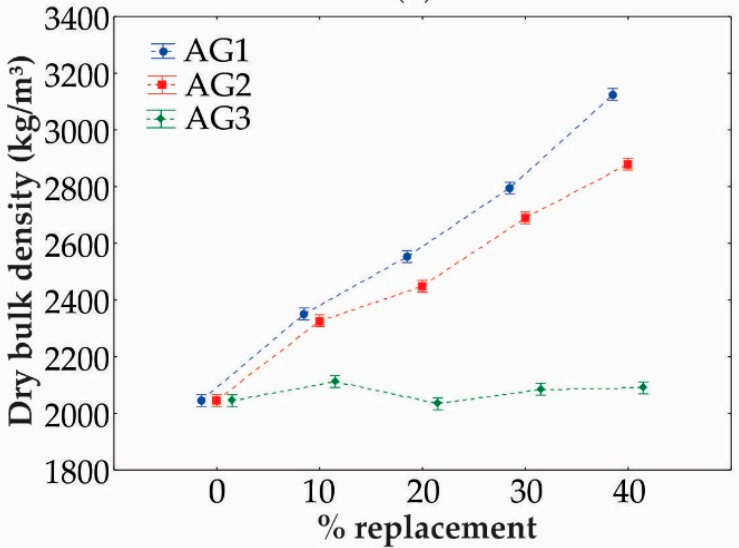

(d)

Figure 10. Graphs of (a) air void, (b) water absorption, and (c) saturated and (d) dry bulk densities in relation to the percentage of substitution for the different types of aggregates.

Figure 10a shows that the air void had similar results for mortars produced with AG1 and AG2 if compared with the results of AG3. While the results of AG1 and AG2 were, for the most part, below the values of the reference mortar. AG3 presented an opposite result, where, with the increase in the percentage of replacement of the aggregate, the air void was higher. This behavior can be explained in relation to the shape and texture, i.e., according to Jamkar et al. [45], the aggregates that have a rougher surface and a more angular shape have more air voids than those that have a smoother texture and a rounded shape. Another explanation for the increase of air void is the decrease in workability due to the presence of the high specific surface area AG3. Similar behavior has been reported by Khatib et al. [46], but another type of waste was used.

As for water absorption by total immersion (Figure 10b), mortar produced from AG1 and AG2 showed a reduction in water absorption in relation to the reference sample, mainly due to the increase in the percentage of metallic particles that do not absorb water. On the other hand, AG3 had the opposite behavior, where there was an increase in the percentage of water absorption due to the percentage of the aggregate replaced. This behavior of AG3 is directly linked to the significant growth in the air void shown in Figure 10a. This increase in water absorption is an indication of an increase in 
the volume of pores. This may be due to the unimodal grain size distribution of AG3 possibly leading to less optimal compacting and therefore a larger volume of pores.

The results for the air void and water absorption of samples developed with AG3 are similar to the results found in the research by Esen and Doğan [44], who also found that increasing the percentage of the aggregate replaced also increased the air void and water absorption. However, these authors used limonite (a mixture of hydrated iron hydroxide in varied compositions $-\mathrm{FeO}(\mathrm{OH}) \cdot \mathrm{nH}_{2} \mathrm{O}$ ) as aggregate.

An opposite effect to the expected was found for the substitution of AG3 in relation to bulk densities (dry and wet), water absorption, and air voids, that is, when adding finer materials in the mortar, the tendency was to increase the packaging and, consequently, decrease water absorption and air voids and increase densities $[47,48]$. However, in the study carried out in mortar by da Silva and Campiteli [49], for a fine particle content of aggregates greater than $20 \%$, the air void and water absorption also increased.

Regarding the saturated (Figure 10c) and dry (Figure 10d) densities, the mortars produced from AG1, AG2, and AG3 showed an increase in densities according to the substitution percentages. AG1, a higher-density waste, showed mixtures with higher bulk density values (dry and saturated). For AG2, the densities were of an intermediate order among the three types of aggregates evaluated, but with very similar behavior. AG3, on the other hand, presented results very close to the results of the reference sample in all replacement percentages used. This low variation in density, compared to that obtained for the reference samples, is a consequence of the higher air void obtained for the materials constituted by AG3. According to Carasek [50], mortars developed with heavy aggregates were characterized by unit weight above $2300 \mathrm{~kg} / \mathrm{m}^{3}$. In this way, mortars produced with AG1 and AG2 aggregates can be classified as heavy-weight mortar. For other authors [10,51,52], heavyweight mortar is defined as mortar with unit weight ranging from 2900 to $6000 \mathrm{~kg} / \mathrm{m}^{3}$, while the unit weight of conventional mortar varies between 2200 and $2450 \mathrm{~kg} / \mathrm{m}^{3}$. Already for Azeez et al. [53], heavy-weight mortar is categorized as a mortar having unit weight above $2600 \mathrm{~kg} / \mathrm{m}^{3}$.

\subsection{X-Ray Shielding}

The attenuation characteristics of the mortars for X-ray energy of $70 \mathrm{kVp}$ were determined and are summarized in Table 5 and Figure 11.

Table 5. Attenuation characteristics of shielding cement materials for X-ray energy of $70 \mathrm{kVp}$. HVL: Half Value Layer; TVL: Tenth Value Layer.

\begin{tabular}{ccccc}
\hline Samples & $\begin{array}{c}\text { Linear Attenuation } \\
\text { Coefficient }\left(\mathbf{m m}^{-\mathbf{1}}\right)\end{array}$ & $\begin{array}{c}\text { 1 mm Lead } \\
\text { Equivalent }\end{array}$ & HVL (mm) & TVL (mm) \\
\hline Lead rubber $(1 \mathrm{~mm})$ & $4.057 \pm 0.031$ & 1 & $0.172 \pm 0.005$ & $0.568 \pm 0.012$ \\
100\% natural sand & $0.046 \pm 0.008$ & $86.84 \pm 2.57$ & $14.936 \pm 1.321$ & $49.618 \pm 1.127$ \\
AG1 10\% & $0.085 \pm 0.003$ & $47.26 \pm 1.37$ & $8.130 \pm 0.098$ & $27.006 \pm 0.991$ \\
AG1 20\% & $0.120 \pm 0.004$ & $33.64 \pm 1.76$ & $5.786 \pm 0.102$ & $19.222 \pm 1.612$ \\
AG1 30\% & $0.153 \pm 0.007$ & $26.34 \pm 1.42$ & $4.531 \pm 0.099$ & $15.051 \pm 1.321$ \\
AG1 40\% & $0.176 \pm 0.006$ & $22.88 \pm 1.15$ & $3.935 \pm 0.087$ & $13.070 \pm 0.789$ \\
AG2 10\% & $0.090 \pm 0.003$ & $44.75 \pm 1.60$ & $7.697 \pm 0.079$ & $25.569 \pm 0.921$ \\
AG2 20\% & $0.127 \pm 0.003$ & $31.72 \pm 2.12$ & $5.457 \pm 0.154$ & $18.126 \pm 1.020$ \\
AG2 30\% & $0.154 \pm 0.004$ & $26.23 \pm 1.80$ & $4.512 \pm 0.201$ & $14.989 \pm 1.720$ \\
AG2 40\% & $0.169 \pm 0.006$ & $23.88 \pm 1.27$ & $4.108 \pm 0.098$ & $13.646 \pm 0.870$ \\
AG3 10\% & $0.075 \pm 0.005$ & $53.62 \pm 1.01$ & $9.223 \pm 0.119$ & $30.638 \pm 2.152$ \\
AG3 20\% & $0.085 \pm 0.003$ & $47.16 \pm 1.67$ & $8.112 \pm 0.143$ & $26.947 \pm 1.221$ \\
AG3 30\% & $0.107 \pm 0.006$ & $37.50 \pm 1.16$ & $6.449 \pm 0.221$ & $21.424 \pm 1.775$ \\
AG3 40\% & $0.114 \pm 0.004$ & $35.36 \pm 2.16$ & $6.082 \pm 0.095$ & $20.203 \pm 1.398$ \\
\hline
\end{tabular}




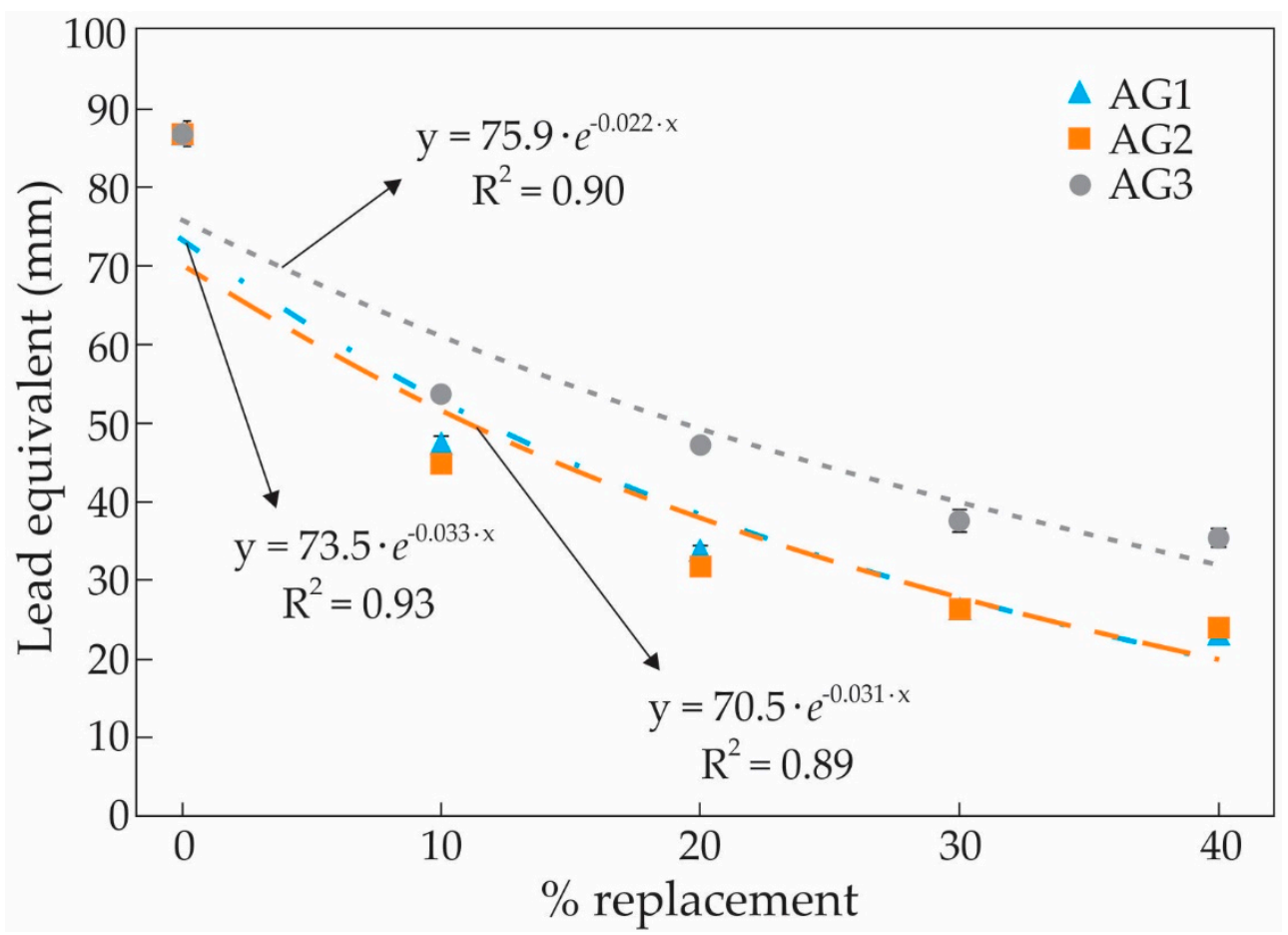

Figure 11. X-ray attenuation due to the percentage of aggregates replaced and types of aggregates.

The mortars produced with wastes AG1, AG2, and steel shot AG3 performed better than the reference mortar samples (cementitious material developed without adding waste steel shot), with an increase in attenuation due to the increase in the percentage of substitution. Samples made with AG1 and AG2 showed similar behaviors, while samples with AG3 presented a lower performance when compared to the AG1 and AG2.

It can be clearly noticed that the linear attenuation coefficient for the samples prepared with $100 \%$ natural sand was significantly lower than the samples prepared with AG1, AG2, and AG3. It is obvious that the denser aggregates (AG1, AG2, and AG3) increased the effectiveness of radiation shielding because they can absorb more radiation photons [54]. According Gencel et al. [55], the performance of the mixtures with respect to neutron shielding might be different due to the different mechanisms of action of neutron particles.

HVL and TVL are the thickness of shielding material required to attenuate the radiation by half and $90 \%$, respectively. As can be seen in Table 5, the HVL and TVL are always inversely proportional to the linear attenuation coefficient. The $1 \mathrm{~mm}$ lead equivalent values also showed a similar trend. For example, if a proactive layer with a lead equivalent of $1 \mathrm{~mm}$ is required, $86.8 \mathrm{~mm}$ of a sample with $100 \%$ natural sand is needed. However, using a denser shielding aggregate can considerably reduce the materials to achieve the same effect. The thickness can be reduced by about $76.7 \%, 72.5 \%$, and $59.3 \%$ when natural sand is replaced by $40 \%$ of AG1, $40 \%$ of AG2, and $40 \%$ of AG3, respectively. This improvement may be obtained from the heavy metal elements in AG1, AG2, and AG3, e.g., iron (Fe) $[39,56]$.

The study by Maslehuddin et al. [18], which used steel shot and blast furnace slag, corroborates the results obtained as they observed that the concrete produced with $100 \%$ shot had the highest attenuation coefficient. Waly and Bourham [20] presented a study where the use of a combination with $39 \%$ magnetite and $16 \%$ lead oxide obtained an attenuation of approximately nine times greater than the reference concrete. The study by Ling et al. [21], which used different aggregates, found similar results, i.e., using a denser shielding mortar can considerably reduce the materials to achieve the same effect. The thickness can be reduced by about $75.6 \%$ when sand mortar is replaced by barite mortars. 
Figure 12 shows the radiographs from the $\mathrm{X}$-ray test of materials produced from waste AG1 (Figure 12b-e), AG2 (Figure 12f-i), AG3 (Figure 12j-m), and the reference sample (Figure 12a).

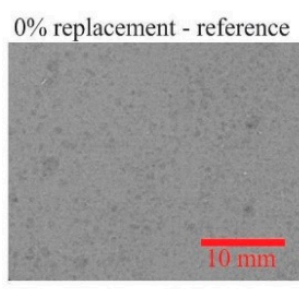

(a)

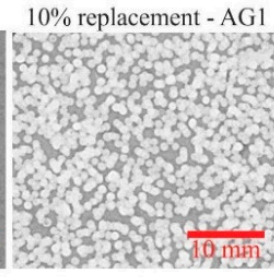

(b)

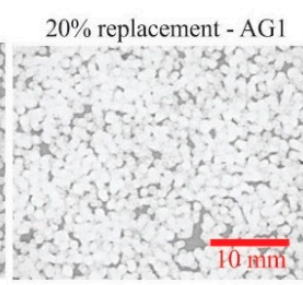

(c)

$30 \%$ replacement - AG1

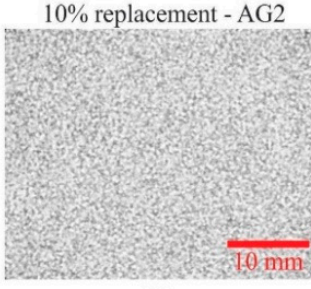

(f)

$20 \%$ replacement - AG2

$30 \%$ replacement - AG2

(d)

$40 \%$ replacement - AG2
$40 \%$ replacement - AG1

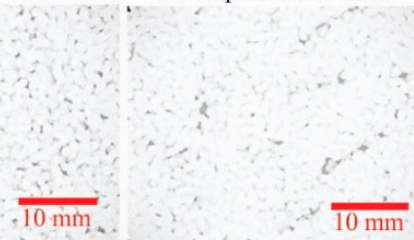

(e)

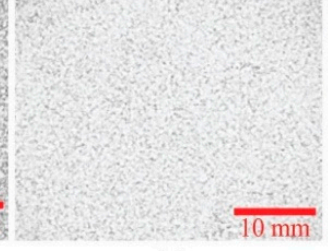

(g)

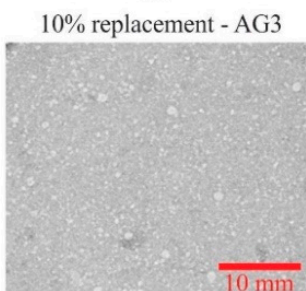

(j)

$20 \%$ replacement - AG3

$30 \%$ replacement - AG3

$40 \%$ replacement - AG3

(i)

(h)

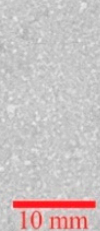

(k)

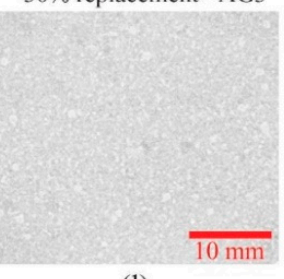

(1)

Figure 12. Radiography of the specimens: (a) reference sample, (b-e) AG1, (f-i) AG2 and (j-m) AG3.

It is observed that the higher the percentage of aggregates (AG1, AG2, and AG3) is used, the greater the number of gray images (whiter images) is and, consequently, the greater the X-ray attenuation generated by the sample is.

The effect of X-ray shielding is provided by the metal shot particles, and thus, another aspect of the mixture can be observed, which is the homogenization in the distribution of the metal particles. In the case of AG1, this was considered satisfactory, since there was a concern that, depending on the density of the particles, there could be a concentration at the bottom of the sample. It can also be observed that the materials produced with AG2 and AG3 showed a more homogeneous distribution of the metallic particles than the materials produced with AG1, mainly because the aggregates have smaller particles.

\section{Conclusions}

This study presented an analysis on the use of a particular type of metallic waste, known as steel shot waste, with a view to proposing its use in heavy mortar, which has a specific application in the civil construction sector, mainly in bulkheads in installations that emit radiation such as hospitals, $X$-ray rooms, reactors, and nuclear power plants.

The assays showed results of compressive strength above the minimum compressive strength (20 MPa) requirement of structural concrete, with the optimal percentage of replacement of sand being $20 \%$.

Air void results were significantly influenced by the type of heavy aggregate and percentage of substitution (natural sand by heavy aggregate), concluding that the use of AG3 aggregate contributes to the increase in the air void for mortar due to its shapes and the greater difficulty in sliding the grains if compared to natural aggregates. For AG1 and AG2 aggregates, the air voids were similar or lower than the reference mortar. 
Water absorption of mixtures produced with AG1 and AG2 decreased in accordance with the increase in the percentage of substitution. This was because of the relatively low water absorption of AG1 and AG2 residue and the dense structure of the cement mortar incorporating AG1 and AG2 residue. While AG3 had the opposite behavior, which once more is explained by the shape of the grain and possible contaminants contained in this waste.

The densities of the materials using AG1 and AG2 increased more than those of the materials produced with AG3. The characteristic of attenuating X-ray radiation obtained a better result than the reference mortar, the values increasing according to the increase in the substitution.

Based on the results, it can be concluded that the mortar produced with AG1, AG2, and AG3 wastes has characteristics that allow it to be used for the purpose of attenuating X-ray radiation. The AG3 sample performed smaller than the AG1 and AG2. However, it was better than that of the reference mixtures.

According to the research objectives, it is concluded that steel shot waste can be used in the development of heavy mortar for the purposes of shielding from radiation. However, more of its properties, e.g., durability and workability among other characteristics, must be subject to further evaluation.

Author Contributions: R.T.L. and M.B.P. planned the study, performed the tests, analyzed the results, and wrote the paper. R.d.A.S. and F.T.B. assisted in the analysis of the results and with writing the paper. All authors have read and agreed to the published version of the manuscript.

Funding: This research received no external funding.

Acknowledgments: The authors would like to thank Fundação Meridional and Coordenação de Aperfeiçoamento de Pessoal de Nivel Superior (CAPES) for support.

Conflicts of Interest: The authors declare no conflict of interest.

\section{References}

1. Moura, W.A.; Dal Molin, D.C.C. Influência da adição de escória de cobre em características relacionadas à durabilidade do concreto. Ambiente Construído 2004, 4, 41-56.

2. Alwaeli, M. The implementation of scale and steel chips waste as a replacement for raw sand in concrete manufacturing. J. Clean. Prod. 2016, 137, 1038-1044. [CrossRef]

3. Associação Brasileira de Normas Técnicas (ABNT). NBR 10004: Resíduos Sólidos: Classificação; Associação Brasileira de Normas Técnicas: Rio de Janeiro, Brazil, 2004.

4. CONAMA. Resolução No 303 de 20 de Março de 2002; Conselho Nacional do Meio Ambiente: Brasília, Brazil, 2002.

5. Nacional, C. Resíduos sólidos: Comentários à Lei 12,305/2010; CONAMA: Brasília, Brazil, 2010.

6. Buruiana, D.L.; Bordei, M.; Diaconescu, I.; Ciurea, A. Recycling options for used sandblasting grit into road construction. In Recent Researches in Energy Environment Landscape Architecture; Thomas, G., Fleaurant, C., Panagopoulos, T., Chevassus-Lozza, E., Zaharim, A., Sopian, K., Eds.; WSEAS Press: Angers, France, 2011; Volume 1, p. 182.

7. Makarious, A.; Bashter, I.; Abdo, A.E.-S.; Azim, M.S.A.; Kansouh, W. On the utilization of heavy concrete for radiation shielding. Ann. Nucl. Energy 1996, 23, 195-206. [CrossRef]

8. Ouda, A.S. Development of high-performance heavy density concrete using different aggregates for gamma-ray shielding. Prog. Nucl. Energy 2015, 79, 48-55. [CrossRef]

9. Akkurt, I.; Basyigit, C.; Kilincarslan, S.; Mavi, B.; Akkurt, A. Radiation shielding of concretes containing different aggregates. Cem. Concr. Compos. 2006, 28, 153-157. [CrossRef]

10. Binici, H.; Aksogan, O.; Sevinc, A.H.; Kucukonder, A. Mechanical and radioactivity shielding performances of mortars made with colemanite, barite, ground basaltic pumice and ground blast furnace slag. Constr. Build. Mater. 2014, 50, 177-183. [CrossRef]

11. Maslehuddin, M.; Naqvi, A.; Ibrahim, M.; Kalakada, Z. Radiation shielding properties of concrete with electric arc furnace slag aggregates and steel shots. Ann. Nucl. Energy 2013, 53, 192-196. [CrossRef]

12. Topcu, İ.B. Properties of heavyweight concrete produced with barite. Cem. Concr. Res. 2003, 33, 815-822. [CrossRef] 
13. La, L.B.; Leong, Y.-K.; Leatherday, C.; Au, P.I.; Hayward, K.J.; Zhang, L.-C. X-ray protection, surface chemistry and rheology of ball-milled submicron Gd2O3 aqueous suspension. Colloids Surf. A Physicochem. Eng. Aspects 2016, 501, 75-82. [CrossRef]

14. Monzen, H.; Kanno, I.; Fujimoto, T.; Hiraoka, M. Estimation of the shielding ability of a tungsten functional paper for diagnostic x-rays and gamma rays. J. Appl. Clin. Med. Phys. 2017, 18, 325-329. [CrossRef]

15. Sopapan, P.; Laopaiboon, J.; Jaiboon, O.; Yenchai, C.; Laopaiboon, R. Feasibility study of recycled CRT glass on elastic and radiation shielding properties used as x-ray and gamma-ray shielding materials. Prog. Nucl. Energy 2020, 119, 103149. [CrossRef]

16. Gaafar, M.; Mahmoud, I. Structural investigation and interpretation of some alkali lead borate glasses as radiation shielding materials. J. Aust. Ceram. Soc. 2019, 55, 865-872. [CrossRef]

17. AbuAlRoos, N.J.; Amin, N.A.B.; Zainon, R. Conventional and new lead-free radiation shielding materials for radiation protection in nuclear medicine: A review. Radiat. Phys. Chem. 2019, 165, 108439. [CrossRef]

18. Kothan, S.; Kaewkhao, J.; Kim, H.; Muangmala, W.; Kiatwattanacharoen, S.; Jumpee, C.; Kaewjaeng, S. Structural and Radiation Shielding Properties of Dy3+ doped Phosphate Glasses. J. Phys. Conf. Ser. 2020, 1428, 012016. [CrossRef]

19. Jaiyen, S.; Phumsuwan, A.; Thongpool, V.; Phunpueok, A. Determination of Radiation Attenuation Coefficients of Rubber Containing Barite. Appl. Mech. Mater. 2017, 2017, 204-207. [CrossRef]

20. El-Samrah, M.G.; Abdel-Rahman, M.A.; Kany, A.M. Study characteristics of new concrete mixes and their mechanical, physical, and gamma radiation attenuation features. Z. Anorg. Allg. Chem. 2018, 644, 92-99. [CrossRef]

21. Ling, T.-C.; Poon, C.-S.; Lam, W.-S.; Chan, T.-P.; Fung, K.K.-L. X-ray radiation shielding properties of cement mortars prepared with different types of aggregates. Mater. Struct. 2013, 46, 1133-1141. [CrossRef]

22. Waly, E.-S.A.; Bourham, M.A. Comparative study of different concrete composition as gamma-ray shielding materials. Ann. Nucl. Energy 2015, 85, 306-310. [CrossRef]

23. Creutz, E.; Downes, K. Magnetite concrete for radiation shielding. J. Appl. Phys. 1949, 20, $1236-1240$. [CrossRef]

24. Meneghel, L. Aproveitamento de Resíduos de Granalha de Aço-Carbono Por Metalurgia do pó. Master's Thesis, Brazil Programa de Pós-graduação em Engenharia e Ciência dos Materiais, Universidade de Caxias do Sul-UCS, Caxias do Sul, RS, Brazil, 2017.

25. Qomariah, Q.; Sugiharti, S.; Riyanto, S. The Utilization of Sandblasting Sand Waste for Mortar and Normal Concrete; IOP Conference Series: Materials Science and Engineering; IOP Publishing: Bristol, UK, 2020; p. 012036.

26. Partial Replacement of Cement in Concrete by Steel Shot Dust. Available online: https://zenodo.org/record/ 400981\#.XzwDpOhKhPY (accessed on 17 August 2020).

27. Sinto. Granalha de aço-Jateamento e shot peening. In Catálogo Comercial, 2012; Catalogo: São Paulo, SP, Brasil, 2012.

28. Associação Brasileira de Normas Técnicas (ABNT). NBR 10007: Amostragem de Resíduos-Procedimento; ABNT: Rio de Janeiro, Brasil, 2004.

29. Associação Brasileira de Normas Técnicas (ABNT). NBR NM 248: Agregados-Determinação da Composição Granulométrica; ABNT: Rio de Janeiro, Brasil, 2003.

30. Associação Brasileira de Normas Técnicas (ABNT). D854-14-Standard Test Methods for Specific Gravity of Soil Solids by Water Pycnometer; ASTM International: West Conshohocken, PA, USA, 2014.

31. Associação Brasileira de Normas Técnicas (ABNT). NBR ISO 2597-2 Iron Ores: Determination of Total Iron Content, Part 2, Titrimetric Methods after Titanium (III) Chloride Reduction; Associação Brasileira de Normas Técnicas: Rio de Janeiro, Brasil, 2013.

32. Associação Brasileira de Normas Técnicas (ABNT). NBR 5738: Concreto-Procedimento Para Moldagem e Cura de Corpos de Prova; ABNT: Rio de Janeiro, Brasil, 2015.

33. Associação Brasileira de Normas Técnicas (ABNT). NBR 5739: Concreto-Ensaio de Compressão de Corpos-De-Prova Cilíndricos; Associação Brasileira de Normas Técnicas: Rio de Janeiro, Brasil, 2018.

34. Associação Brasileira de Normas Técnicas (ABNT). C948-81 Standard Test Method for dry and wet bulk Density. In Water Absorption, and Apparent Porosity of Thin Sections of Glass-Fibre Reinforced Concrete; American Society for Testing and Materials: West Conshohocken, PA, USA, 2009. 
35. Associação Brasileira de Normas Técnicas (ABNT) 9778. NBR 9779: Argamassa e Concreto Endurecidos: Determinação da Absorção de Água, Índice de Vazios e Massa Específica; Associação Brasileira de Normas Técnicas: Rio de Janeiro, Brasil, 2009.

36. Paiva, E.D. Princípios do cálculo de blindagem em radioterapia. Rev. Bras. Ensino Fís. 2014, 36, 1-5. [CrossRef]

37. Shamsuzzaman, M.; Khan, M.A.M.; Bhuiyan, M.M.H.; Rahman, M.S.; Khan, M.J.H.; Paul, D.; Sarkar, D.R. Attenuation Property of Wood and Fiber Reinforced Polymer Composite Materials for Neutron and Gamma Radiation Shielding. Am. J. Mater. Sci. 2019, 9, 7. Available online: http://article.sapub.org/10.5923.j.materials. 20190901.02.html (accessed on 17 August 2020).

38. Fathi, I.; Mkimel, M.; Halimi, A.; Mesradi, M.; Krim, M.; Saad, E.; Hilali, A. Experimental characterization and Monte Carlo simulation of radiation dose in mammography by AGMS-DM+ and OSL nanoDot ${ }^{\mathrm{TM}}$ detectors. In Proceedings of the 2019 IEEE International Symposium on Medical Measurements and Applications (MeMeA), Istanbul, Turkey, 26-28 June 2019; pp. 1-5.

39. Kunchariyakun, K.; Sukmak, P. Utilization of garnet residue in radiation shielding cement mortar. Constr. Build. Mater. 2020, 262, 120122. [CrossRef]

40. American Society for Testing and Materials. C 136: Standard Test Method for Sieve Analysis of Fine and Coarse Aggregates; ASTM International: West Conshohocken, PA, USA, 2006.

41. Skoog, D.A.; West, D.M.; Holler, F.J. Fundamentos de Química Analítica; Reverté: Barcelona, Spain, 1997; Volume 2.

42. Associação Brasileira de Normas Técnicas (ABNT). NBR 8953: Concreto para fins estruturais-Classificação pela massa específica, por grupos de resistência e consistência. In ABNT/CB-018 Cimento, Concreto e Agregados; Associação Brasileira de Normas Técnicas: Rio de Janeiro, Brazil, 2015.

43. Kan, Y.-C.; Pei, K.-C.; Chang, C.-L. Strength and fracture toughness of heavy concrete with various iron aggregate inclusions. Nucl. Eng. Des. 2004, 228, 119-127. [CrossRef]

44. Esen, Y.; Doğan, Z.M. Investigation of usability of limonite aggregate in heavy-weight concrete production. Prog. Nucl. Energy 2018, 105, 185-193. [CrossRef]

45. Jamkar, S.; Rao, C. Index of aggregate particle shape and texture of coarse aggregate as a parameter for concrete mix proportioning. Cem. Concr. Res. 2004, 34, 2021-2027. [CrossRef]

46. Khatib, J.; Herki, B.; Kenai, S. Capillarity of concrete incorporating waste foundry sand. Constr. Build. Mater. 2013, 47, 867-871. [CrossRef]

47. Cordeiro, L.d.N.P.; Paes, I.N.L.; Souza, P.S.L.; Azevedo, C.M. Caracterização da cinza de caroço de açaí residual para adição ao concreto. Ambiente Construído 2019, 19, 45-55. [CrossRef]

48. Kazmierczak, C.d.S.; Rosa, M.; Arnold, D.C.M. Influência da adição de filer de areia de britagem nas propriedades de argamassas de revestimento. Ambiente Construído 2016, 16, 7-19. [CrossRef]

49. da Silva, N.G.; Campiteli, V.C. Influência dos finos e da cal nas propriedades das argamassas. In XI Encontro Nacional de Tecnologia no Ambinete Construido; ENTAC: Florianópolis, Brasil, 2006.

50. Carasek, H. Argamassas. In Materiais de Construção Civil e Princípios de Ciência e Engenharia de Materiais, 2nd ed.; Isaia, G.C.E.A., Ed.; Ibracon: São Paulo, Brazil, 2010; Volume 2.

51. Akkurt, I.; Basyigit, C.; Kilincarslan, S.; Mavi, B. The shielding of c-rays by mortars produced with barite. Prog. Nucl. Energy 2005, 46, 1-11. [CrossRef]

52. Demir, F.; Budak, G.; Sahin, R.; Karabulut, A.; Oltulu, M.; Şerifoğlu, K.; Un, A. Radiation transmission of heavyweight and normal-weight concretes containing colemanite for $6 \mathrm{MV}$ and $18 \mathrm{MV}$ X-rays using linear accelerator. Ann. Nucl. Energy 2010, 37, 339-344. [CrossRef]

53. Azeez, M.O.; Ahmad, S.; Al-Dulaijan, S.U.; Maslehuddin, M.; Naqvi, A.A. Radiation shielding performance of heavy-weight concrete mixtures. Constr. Build. Mater. 2019, 224, 284-291. [CrossRef]

54. Ling, T.-C.; Poon, C.-S.; Lam, W.-S.; Chan, T.-P.; Fung, K.K.-L. Utilization of recycled cathode ray tubes glass in cement mortar for X-ray radiation-shielding applications. J. Hazard. Mater. 2012, 199, 321-327. [CrossRef] [PubMed] 
55. Gencel, O.; Bozkurt, A.; Kam, E.; Korkut, T. Determination and calculation of gamma and neutron shielding characteristics of concretes containing different hematite proportions. Ann. Nucl. Energy 2011, 38, 2719-2723. [CrossRef]

56. Abd Elwahab, N.R.; Helal, N.; Mohamed, T.; Shahin, F.; Ali, F.M. New shielding composite paste for mixed fields of fast neutrons and gamma rays. Mater. Chem. Phys. 2019, 233, 249-253. [CrossRef]

(C) 2020 by the authors. Licensee MDPI, Basel, Switzerland. This article is an open access article distributed under the terms and conditions of the Creative Commons Attribution (CC BY) license (http://creativecommons.org/licenses/by/4.0/). 